\title{
KONJUNGSI PADA HARIAN RAKYAT BENGKULU
}

\author{
'Monika Puspita Sari; ${ }^{2}$ Bambang Djunaidi; ${ }^{3}$ Supadi \\ 1,2,3 Program Studi Pendidikan Bahasa Indonesia FKIP Universitas Bengkulu
}

\section{Abstrak}

\section{Korespondensi: Monikapuspitasari4@gmail.com}

Penelitian ini bertujuan untuk mendeskripsikan jenis, fungsi dan makna konjungsi intrakalimat Harian Rakyat Bengkulu edisi Februari 2019.Data dalam penelitian ini adalah kalimat yang mengandung konjungsi. Metode yang digunakan dalam penelitian ini adalah metode deskriptif. Teknik pengumpulan data yang digunakan adalah teknik dokumentasi. Teknik analisis data yang digunakan yaitu teknik delesi, dan teknik substitusi. Hasil penelitian ini ditemukan konjungsi koordinatif, konjungsi subordinatif dan konjungsi korelatif. Berdasarkan analisis data yang diperoleh, konjungsi koordinatif yaitu konjungsi dan, serta, atau, namun, lalu, sedangkan, kemudian, yaitu, dan adalah. Konjungsi subordinatif yaitu konjungsi sejak, hingga, setelah, selama, sampai, jika, kalau, sebingga, karena, sebab, sebagai, dengan, bahwa. Konjungsi korelatif yaitu konjungsi dan...serta, dan...atau, atau...serta, dan...namun, dan...kemudian, atau...adalah, dan...sejak, hingga...dan, karena...kemudian, dan...dengan. Fungsi konjungsi yaitu (1) menghubungkan kalimat luas yang setara, (2) menghubungkan kalimat luas yang tidak setara dan, (3) menghubungkan klausa dengan klausa. Makna konjungsi dalam penelitian ini yaitu (1) makna penjumlahan, (2) makna pemilihan, (3) makna pertentangkan, (4) makna pengurutan, (5) makna penyamaan, (6) makna waktu, (7) makna persyaratan, (8) makna hasil, (9) makna sebab, (10) makna perbandingan, (11) makna alat, dan (12) makna isi. Berdasarkan hasil penelitian dapat disimpulkan bahwa konjungsi intrakalimat yakni konjungsi koordinatif, konjungsi subordinatif dan konjungsi korelatif pada kolom utama Harian Rakyat Bengkulu edisi Februari 2019.

Kata kunci: jenis konjungsi, fungsi konjungsi, makna konjungsi

\section{Abstract}

This study aimed to describe the types, functions and meanings of Harian Rakyat Bengkulu February 2019 Edition's Intrasentence Conjunction. The data in this study were sentences containing conjunctions. The method used in this research was descriptive method. The data collection technique used was documentation technique. Data analysis techniques used were deletion techniques, and substitution techniques. The results found from this study were coordinative conjunctions, subordinative conjunctions and correlative conjunctions. Based on the analysis of data obtained, coordinative conjunctions were conjunctions in form of and, as well as, or, however, then, whereas, then, that is, and are. Subordinative conjunctions were conjunctions in form of from, until, after, during, until, if, if, so that, because of, because, as, with, that. Correlative conjunctions were conjunctions in form of and $\ldots$ and, and $\ldots$ or, or ... and, and ... however, and ... then, or ... are, and ... from, until ... and, because ... then, and ... with. The functions of Conjunction were (1) connecting equivalent broad sentences, (2) connecting unequal broad sentences and, (3) connecting clauses with clauses. The meaning of conjunctions in this study 


\section{Monika Puspita Sari, Bambang Djunaidi, Supadi}

were (1) the meaning of addition, (2) the meaning of election, (3) the meaning of contradiction, (4) the meaning of sorting, (5) the meaning of equalization, (6) the meaning of time, (7) the meaning of requirements, (8) ) the meaning of the results, (9) the meaning of cause, (10) the meaning of comparison, (11) the meaning of tools, and (12) the meaning of content. Based on the results of the study it can be concluded that intra sentence conjunctions were coordinative conjunctions, subordinative conjunctions and correlative conjunctions in the February 2019 edition of the Harian Rakyat Bengkulu's Main column.

Keywords: types of conjunctions, functions of conjunctions, conjunctions meaning

\section{PENDAHULUAN}

Bahasa adalah alat komunikasi bagi manusia untuk menyampaikan gagasan, pemikiran, pendapat kepada masyarakat atau lingkungan sosialnya. Setiap daerah memiliki kekhasan bahasa masing-masing, namun walaupun bahasa di setiap daerah berbeda ada kesamaan yang dimiliki oleh bahasa-bahasa tersebut yaitu konjungsi, dalam komunikasi baik secara lisan maupun tulisan. Konjungsi berfungsi menghubungkan antar kata, frasa, klausa, dan kalimat dalam sebuah wacana. Adanya konjungsi akan membantu komunikasi berjalan dengan lancar.

Chaer (2015:98) mengatakan bahwa konjungsi atau kata penghubung adalah kata-kata yang menghubungkan satuan-satuan sintaksis, baik antar kata dengan kata, antar frase dengan frase, antar klausa dengan klausa atau antar kalimat dengan kalimat. Dengan adanya konjungsi akan membuat komunikasi kita lebih lancar dan jelas dibandingkan tidak menggunakan konjungsi.

Ramlan (2008:39) mengatakan bahwa berdasarkan sifat hubungannya, kata penghubung dapat dibedakan menjadi dua, yaitu kata penghubung yang setara atau koordinatif dan kata penghubung tidak setara atau subordinatif. Rahardi (2009:14) mengatakan bahwa dari sisi perilaku sintaksisnya dalam sebuah kalimat-karena sejatinya makna sebuah konjungsi atau kata penghubung sesungguhnya akan dapat benar-benar kelihatan dengan jelas jika konjungsi atau kata penghubung itu dibicarakan dalam konteks klausa atau kalimat. konjungsi atau kata penghubung dalam bahasa Indonesia itu ternyata dapat dibagi menjadi empat jenis, yaitu: (1) konjungsi koordinatif, (2) konjungsi korelatif, (3) konjungsi subordinatif, dan (4) Konjungsi antarkalimat.

Konjungsi dapat terletak dalam kalimat atau disebut juga konjungsi intrakalimat. Rahardi (2002:65) mengatakan bahwa intrakalimat menghubungkan entitas kebahasaan yang ada dalam suatu kalimat dan terletak di tengah-tengah kalimat. Chaer (2009:112) mengatakan bahwa intrakalimat merupakan penghubung satuan-satuan kata dengan kata, frasa dengan frasa atau klausa dengan klausa yang berada di dalam sebuah kalimat. Jika dilihat dalam pembagiannya fungsi maka konjungsi koordinatif, konjungsi subordinatif dan konjungsi korelatif termasuk dalam konjungsi intrakalimat.

Alwi (2010:317) mengatakan bahwa kalimat adalah satuan bahasa terkecil, dalam wujud lisan atau tulis, yang mengungkapkan pikiran yang utuh, dalam wujud lisan, kalimat diucapkan dengan suara naik, turun dan keras lembut, disela jeda dan diakhiri intonasi akhir yang diikuti oleh kesenyapan yang mencegah terjadinya perpaduan ataupun asimilasi bunyi ataupun proses fonologis lainnya. 
Konjungsi adalah unsur yang sangat penting, yang sering tidak dipedulikan oleh penulis, konjungsi yang kurang tepat atau salah dalam pemakaiannya dapat mengubah makna atau pesan yang ingin disampaikan oleh penulis kepada pembaca. Konjungsi dapat ditemukan dalam komunikasi lisan maupun tulis, dalam ragam tulis dapat dilihat di media cetak yaitu, majalah, koran, dan jurnal. Dalam hal ini penulis memilih Harian Rakyat Bengkulu kolom utama karna dalam kolom tersebut memuat berita-berita utama dan terkini selingkup Provinsi Bengkulu dan nasional, yang sedang hangat di kalangan masyarakat. Pemakaian konjungsi harus jelas fungsi dan maknanya, agar masyarakat tidak salah dalam menafsirkan atau memaknai berita yang disampaikan oleh penulis.

Koran Harian Rakyat Bengkulu memiliki banyak kolom seperti kolom utama, kolom borgol, kolom metropolis, kolom pemilu, kolom probis dan kolom all sport. Dengan adanya kolom-kolom tersebut dapat diamati pemakaian konjungsi, dari beberapa kolom yang ada di dalam koran Harian Bengkulu kolom utama menjadi kolom yang banyak dibaca oleh masyarakat, karena menyajikan berita kriminal dan politik yang terjadi setiap harinya di Provinsi Bengkulu dan nasional,

Penelitian tentang konjungsi sudah pernah dilakukan oleh beberapa peneliti diantaranya penelitian yang dilakukan oleh Rahayu (2017) "Analisis Konjungsi pada Tajuk Rencana Surat Kabar Solopos dan Implikasinya Pada Pembelajaran Bahasa Indonesia di SMA". Jika penelitian Rahayu mengkaji konjungsi dan implikasinya dalam pembelajaran, maka penelitian yang akan dilakukan yakni jenis konjungsi, fungsi konjungsi dan makna konjungsi intrakalimat pada kolom utama pada Harian Rakyat Bengkulu edisi Februari 2019

Berdasarkan latar belakang yang telah diuraikan, maka akan dilakukan penelitian mengenai jenis konjungsi, fungsi konjungsi dan makna konjungsi. Adapun rumusan masalah dalam penelitian ini adalah (1) Apa saja jenis konjungsi yang terdapat dalam kolom utama Harian Rakyat Bengkulu edisi Februari 2019? (2) Apa saja fungsi konjungsi yang terdapat dalam kolom utama Harian Rakyat Bengkulu edisi Februari 2019? (3) Bagaimana makna konjungsi yang terdapat dalam kolom utama pada Harian Rakyat Bengkulu edisi Februari 2019?

Ruang lingkup penelitian ini adalah pemakaian konjungsi intrakalimat pada Harian Rakyat Bengkulu edisi Februari 2019. Batasan masalah penelitian ini yakni jenis konjungsi, fungsi konjungsi dan makna konjungsi intrakalimat dalam kolom utama Harian Rakyat Bengkulu edisi Februari 2019. Tujuan penelitian ini adalah (1) mendeskripsikan jenis konjungsi intrakalimat yang terdapat dalam kolom utama pada Harian Rakyat Bengkulu edisi Februari 2019. (2) mendeskripsikan fungsi konjungsi intrakalimat yang terdapat dalam kolom utama pada Harian Rakyat Bengkulu edisi Februari 2019. (3) mendeskripsikan makna konjungsi intrakalimat yang terdapat dalam kolom utama Harian Rakyat Bengkulu edisi Februari 2019.

\section{METODE}

Penelitian ini adalah penelitian kualitatif dengan metode deskriptif. Data dalam penelitian ini adalah kalimat majemuk yang memiliki konjungsi yang terdapat pada Harian Rakyat Bengkulu edisi Februari 2019. Sumber data dalam penelitian ini adalah kolom utama pada Harian Rakyat Bengkulu edisi Februari 2019. Teknik pengumpulan data dalam penelitian ini adalah dokumentasi dan teknik catat. Dokumen yang didapatkan dalam penelitian ini berupa wacana berita yang terdapat dalam kolom utama Harian Rakyat 
Bengkulu edisi Februari 2019. Analisis data pada penelitian ini menggunakan teknik distribusional dengan teknik analisis delesi dan teknik substitusi. Teknik delesi digunakan untuk menguji konjungsi kalimat setara dan tidak setara apakah dapat dihilangkan atau tidak, sedangkan teknik substitusi digunakan untuk menguji apakah konjungsi kalimat setara dan tidak setara dapat digantikan atau tidak.

\section{HASIL DAN PEMBAHASAN}

\section{Hasil}

Berdasarkan analisis data yang dilakukan diperoleh hasil penelitian terdiri atas tiga aspek yaitu jenis konjungsi, fungsi konjungsi dan makna konjungsi pada Harian Rakyat Bengkulu edisi Februari 2019. Jenis konjungsi yang ditemukan yakni konjungsi koordinatif, konjungsi subordinatif dan konjungsi korelatif. Konjungsi koordinatif yang ditemukan ialah konjungsi dan, serta, atau, namun, sedangkan, kemudian, lalu, yaitu, yakni dan adalah. Konjungsi subordinatif yang ditemukan ialah konjungsi sejak, bingga, setelah, selama, sebelum, sampai, setelah, jika, kalau, sehingga, karena, sebab, sebagai, dengan, bahwa, selain. Konjungsi korelatif yang ditemukan ialah konjungsi dan...serta, dan...atau, atau...serta, dan...namun, dan...kemudian, atau...adalah, dan...sejak, hingga...dan, karena...kemudian, dan...dengan.

Fungsi konjungsi yang ditemukan dalam penelitian ini terbatas pada fungsi konjungsi yang menghubungkan antara kata dan kata, antara frase dan frase dalam kalimat luas yang setara, kalimat luas yang tidak setara dan klausa dengan klausa. Makna konjungsi yang ditemukan yakni makna penjumlahan, makna pemilihan, makna pertentangan, makna pengurutan, makna penyamaan, makna waktu, makna persyaratan, makna hasil, makna sebab, makna perbandingan, makna alat, dan makna isi.

\section{Pembahasan}

Pembahasan dalam penelitian ini sesuai dengan rumusan masalah yaitu berupa deskripsi jenis konjungsi, fungsi konjungsi dan makna konjungsi yang terdapat pada Harian Rakyat Bengkulu edisi Februari 2019. Hasil analisis data sebagai berikut:

A. Jenis Konjungsi

Jenis konjungsi intrakalimat yang ditemukan dalam Hariyan Rakyat Bengkulu edisi Februari 2019, ada tiga yakni konjungsi koodinatif, konjungsi subordinatif dan konjungsi korelatif

1. Konjungsi Koordinatif

(1) Kata Syaiful Sembari mengatakan bahwa 2 terdakwa lainya yakni Hendrati (Istri Dirwan) dan Nursilawati (keponakan Dirwan) juga tidak banding. (II/1)

Kalimat pada contoh data (1) di atas konjungsi dan menyatakan penjumlahan karena menjumlahkan klausa pertama yaitu Kata Syaiful Sembari mengatakan bahwa terdakwa lainya yakni Hendrati (Istri Dirwan) juga tidak melakukan banding, dengan klausa kedua yakni Kata Syaiful Sembari mengatakan babwa terdakwa lainya yakni Nursilawati (keponakan Dirwan) juga tidak banding. Konjungsi dan menghubungkan dua klausa sehingga menjadi satu kalimat majemuk setara.

2. Konjungsi Subordinatif

(2) Sembari bernyanyi itu, pelaku juga mencekoki korban dengan minuman keras (miras) bingga akhirnya membuat korban mabuk. (II/233) 
Kalimat pada contoh data (2) di atas konjungsi bingga dalam menyatakan waktu karena menerangkan batas waktu akhir yaitu klausa pertama Sembari bernyanyi itu, pelaku juga mencekoki korban dengan minuman keras (miras) sebagai klausa inti, klausa kedua pelaku juga mencekoki korban dengan minuman keras (miras) bingga akbirnya membuat korban mabuk sebagai klausa bawahan. Konjungsi bingga menghubungkan dua klausa sehingga menjadi satu kalimat majemuk bertingkat.

3. Konjungsi Korelatif

(3) Korban langsung berbalik badan dan melihat pelaku serta langsung berusaha merebut kayu dari tangan pelaku. (II/85)

Kalimat pada contoh data (3) di atas terdapat dua konjungsi yakni konjungsi dan...serta, konjungsi dan, serta menyatakan penjumlahan, karena pada kalimat itu menyatakan tiga frase kerja. Yakni klausa Korban langsung berbalik badan, klausa korban melibat pelaku, dan klausa langsung berusaba merebut kayu dari tangan pelaku. Meskipun dan, serta menyatakan penjumlahan namun untuk menjumlahkan kata/frase yang lebih dari dua dibutuhkan konjungsi serta sehingga dalam suatu kalimat akan lebih bervariasi.

B. Fungsi Konjungsi

Fungsi konjungsi yang ditemukan dalam Harian Rakyat Bengkulu edisi Februari 2019 yakni menghubungkan kalimat luas yang setara, kalimat luas yang tidak setara dan menghubungkan klausa dengan klausa.

1. Menghubungkan Kalimat Luas yang Setara

(4) Berkas tersebut lengkap (P21) dan bisa dilanjutkan dengan pelimpahan tahap dua atau serah terima tersangka dengan barang bukti. (II/148)

Kalimat pada contoh data (4) di atas terdiri dari dua klausa, klausa pertama Berkas tersebut lengkap (P21) dan bisa dilanjutkan dengan pelimpahan tahap dua, klausa kedua serah terima tersangka dengan barang bukti. Kedua klausa itu berdiri sendiri-sendiri, klausa yang satu tidak merupakan bagian dari klausa lainnya, konjungsi atau dalam kalimat tersebut berfungsi sebagai penghubung klausa. Kalimat pada contoh data (4) di atas tidak dapat didelesi dan disubstitusikan, karena konjungsi atau tidak dapat dihilangkan maupun digantikan dengan konjungsi lain, karena kehadirannya wajib ada dalam kalimat tersebut.

2. Menghubungkan Kalimat Luas yang Tidak Setara

(5) Ridwan menuturkan bingga kemaren belum ada kepastian penentuan kelulusan seleksi komputer apakah berbasis passing prade atau pemeringkatan. (II/246)

Kalimat pada contoh data (5) di atas terdiri dari dua klausa yaitu, klausa Pertama Ridwan menuturkan, klausa kedua Kemaren belum ada kepastian penentuan kelulusan seleksi komputer apakah berbasis passing prade atan pemeringkatan. Klausa pertama merupakan klausa inti klausa kedua merupakan klausa bawahan, Kata bingga merupakan kata penghubung yang berfungsi menghubungkan klausa inti dengan klausa bawahan, dalam hubungannya dengan klausa inti, klausa bawahan menduduku fungsi sebagai (O). Kalimat pada contoh data (5) di atas konjungsi bingga dapat disubstitusikan atau digantikan dengan konjungsi lain, konjungsi bingga tidak dapat didelesikan karena kehadirannya wajib ada.

(5a) Ridwan menuturkan 


$$
\left\{\begin{array}{l}
\text { hingga } \\
\text { sampai }
\end{array}\right\}
$$

kemaren belum ada kepastian penentuan kelulusan seleksi komputer apakah berbasis passing prade atau pemeringkatan. (II/246)

Kalimat pada contoh data (5a) merupakan contoh penerapan teknik substitusi. Konjungsi bingga yang disubstitusikan dengan konjungsi sampai.

3. Menghubungkan Klausa dengan Klausa

(6) Dari 19 wanita yang diamankan, sebagian diantaranya diduga memang bekerja sebagai pemandu lagu (PL), yakni mereka yang saat ini berpakaian minim atau seksi. (II/191)

Kalimat pada contoh data (6) di atas terdiri dari tiga klausa yaitu, klausa pertama Dari 19 wanita yang diamankan, klausa kedua Sebagian diantaranya diduga memang bekerja sebagai pemandu lagu (PL), klausa ketiga Mereka yang saat ini berpakaian minim atau seksi. Klausa pertama Dari 19 wanita yang diamankan menduduki fungsi sebagai (S), klausa kedua Sebagian diantaranya diduga memang bekerja sebagai pemandu lagu (PL) menduduki fungsi sebagai (P), klausa ketiga Mereka yang saat ini berpakaian minim atau seksi, menduduki fungsi sebagai (KET). Kalimat pada contoh data (6) di atas konjungsi yakni dapat disubstitusikan atau digantikan dengan konjungsi lain, konjungsi yakni tidak dapat didelesikan karena kehadirannya wajib ada.

(6a) Dari 19 wanita yang diamankan, sebagian diantaranya diduga memang bekerja sebagai pemandu lagu (PL),

$$
\left\{\begin{array}{l}
\text { yakni } \\
\text { yaitu }
\end{array}\right\}
$$

mereka yang saat ini berpakaian minim atau seksi. (II/191)

Kalimat pada contoh data (6a) merupakan contoh penerapan teknik substitusi. Konjungsi yakni yang disubstitusikan dengan konjungsi yaitu.

C. Makna Konjungsi

Berikut akan dijelaskan makna konjungsi koordinatif yang terdiri dari makna penjumlahan, makna pemilihan, makna pertentangan, makna pengurutan, makna penyamaan dan makna konjungsi subordinatif yang terdiri dari makna waktu, makna persyaratan, makna hasil, makna sebab, makna perbandingan, makna alat, makna isi. 1. Makna Konjungsi Koordinatif

a) Makna Penjumlahan

(7) Sebelumnya, Gisel terlibat dalam tiga film komedi (Susah Sinyal, Cek Tokoh Sebelah, dan Flight 555) serta, satu film horor (The Secret: Suster Ngesot The Urban Legend). (II/89)

Kalimat pada contoh data (7) di atas konjungsi serta berfungsi menghubungkan klausa pertama Sebelumnya, Gisel terlibat dalam tiga film komedi, dengan klausa kedua Gisel terlibat satu filem horor. Makna serta menyatakan makna penjumlahan, karena menghubungkan dua klausa dalam kalimat sehingga menjadi dua jenis film.

b) Makna Pemilihan 
(8) Gubernur Dr. Rohidin Mersyah, MMA memastikan open bidding atau lelang terbuka jabatan eselon II akan segerah dilakukan dalam waktu dekat ini. (II/122)

Kalimat pada contoh data (8) di atas konjungsi atau berfungsi menghubungkan klausa Gubernur Dr. Rohidin Mersyah, MMA memastikan oppen bidding eselon II akan segerah dilakukan dalam waktu dekat ini dengan klausa Gubernur Dr. Rohidin Mersyah, MMA memastikan lelang terbukak eselon II akan segerah dilakukan dalam waktu dekat ini. Konjungsi atau menyatakan makna pemilihan karena menghubungkan dua klausa dalam satu kalimat sehingga menjadi dua pilihan.

c) Makna Pertentangan

(9) Tanpa uang arisan itu Yasumi tak akan bisa berobat ke dokter praktik, sedangkan rasa sakit yang dirasakan Yasumi bila tidak minum obat dapat membuat tubuhnya bengkak.(II/168)

Kalimat pada contoh data (9) di atas kata sedangkan menghubungkan klausa pertama Tanpa uang arisan itu Yasumi tak akan bisa berobak ke dokter prektek, dengan klausa kedua Rasa sakit yang dirasakan Yasumi bila tidak minum obat dapat membuat tububnya bengkak. Konjungsi sedangkan yang menyatakan makna pertentangan karena menghubungkan dua klausa dalam satu kalimat sehingga menjadi dua klausa yang bertentangan.

d) Makna Pengurutan

(10) Setelah meletakan cika, pelaku kembali ke kamar belakang dengan mengambil kabel colokan listrik, lalu membawanya menuju kamar Lili. (II/184)

Kalimat pada contoh data (10) di atas konjungsi lalu menjadi penghubung antara, klausa pertama Setelah meletakan cika, pelaku kembali ke kamar belakang dengan mengambil kabel colokan listrik, dengan klausa kedua Pelaku membawanya Cika menuju kamar Lili. Konjungsi lalu menyatakan makna pengurutan, karena menghubungkan dua klausa dalam satu kalimat sehingga menjadi dua klausa yang berurutan.

e) Makna Penyamaan

(11) Sabtu malam (2/2) anggota Polres Bengkulu menggelar razia di 3 tempat Karaoke keluarga yakni Ayu Ting-Ting, Trople Z, dan Inul Vista. (II/190)

Kalimat pada contoh data (11) di atas konjungsi yakni menjadi penghubung penyamaan antara Karaoke keluarga yakni Ayu Ting-Ting, Trople Z, dan Inul Vista, konjungsi yakni menyatakan makna penyamaan, karena menyamakan nama yang disebutkan dalam inti kalimat tersebut.

2. Makna Konjungsi Subordinatif

a) Makna Waktu

(12) Sembari bernyanyi itu, pelaku juga mencekoki korban dengan minuman keras (miras) bingga akhirnya membuat korban mabuk. (II/233)

Kalimat pada contoh data (12) di atas kata hingga mengatakan klausa Sembari bernyanyi itu, pelaku juga mencekoki korban dengan minuman keras (miras), dengan klausa Sembari bernyanyi itu, pelaku juga mencekoki korban dengan minuman 
akbirnya membuat korban mabuk. Konjungsi hingga menyatakan makna waktu untuk menyatakan batas waktu akhir.

b) b. Makna Persyaratan

(13) Tapi terlepas dari itu, kalau memang itu masih tanggung jawab Pemprov perbaiki saja, gunakan dana rutin itu tegas Helmi. (II/291)

Kalimat pada contoh data (13) di atas konjungsi kalau menyatakan hubungan syarat dimana yang dinyatakan pada konjungsi kalau menerangkan, kalau memang itu masih tanggung jawab Pemprov perbaiki saja gunakan dana rutin itu tegas Helmi. Konjungsi kalau menyatakan makna syarat karena anak kalimat menyatakan syarat terjadinya tindakan atau kejadian pada kalimat induk.

c) c. Makna Hasil

(14) Dengan surat edaran Sekda ini, sehingga banyak proyek di Dinas Pekerjaan Umum yang dihapus kontraknya alias tidak diperpanjang. (II/298)

Kalimat pada contoh data (14) di atas konjungsi sehingga menyatakan hubungan hasil dimana yang dinyatakan pada konjungsi sehingga menerangkan, klausa sehingga banyak proyek di Dinas Pekerjaan Umum yang dihapus kontraknya alias tidak diperpanjang. Konjungsi sebingga menyatakan makna hasil karena menerangkan hasil dari klausa inti.

d) d. Makna Sebab

(15) Hingga saat ini, belum diketahui persis berapa orang rekan Ra yang ikut manggagahi korban tersebut, karena memang saat kejadian korban juga dalam kondisi tidak sadarkan diri. (II/328)

Kalimat pada contoh data (15) di atas konjungsi karena menyatakan klausa pertama Hingga saat ini, belum diketahui persis berapa orang rekan Ra yang ikut manggagabi korban tersebut, dengan klausa kedua Memang saat kejadian korban juga dalam kondisi tidak sadarkan diri. Konjungsi karena mengatakan makna sebab karena klausa bawah mengatakan sebab atau alasan terjadinya atau dilakukannya tindakan yang tersebut dalam klausa inti.

e) Makna Perbandingan

(16)Ditemui terpisah sandi mengungkapkan rasa syukurnya bisa berkunjung ke Bengkulu yang menurutnya sebagai tanah sejarah yang sangat berharga bagi perjalanan kemerdekaan RI. (II/389)

Kalimat pada contoh data (16) di atas konjungsi sebagai menyatakan, klausa pertama Ditemui terpisah sandi mengungkapkan rasa syukurnya bisa berkunjung ke Bengkulu sebagai klausa inti, dengan klausa kedua Tanah sejarah yang sangat berbarga bagi perjalanan kemerdekaan RI sebagai klausa bawahan. Konjungsi sebagai menyatakan makna perbandingan karena membanding- kan antara apa yang dinyatakan pada dua klausa tersebut.

f) f. Makna Alat

(17)Namun sepertinya pelaku ingin memastikan korban meninggal dengan mengambil kabel laptop di atas meja belajar dan langsung melilitkan ke leher korban dengan maksud mencekiknya. (II/410)

Kalimat pada contoh data (17) di atas konjungsi dengan menyatakan klausa pelaku mengambil kabel laptop diatas meja belajar dan langsung melilitkan keleher korban dengan maksud mencekiknya. Konjungsi dengan menyatakan makna alat karena klausa bawahan menyatakan bagaimana perbuatan yang 
disebutkan dalam klausa inti itu dilakukan atau bagaimana klausa peristiwa yang disebutkan dalam klausa inti itu terjadi.

g) g. Makna Isi

(18) Ketua panitia seleksi (Pansel) lelang jabatan eselon II, Drs. Hamka Sabri, M.Si mengatakan, babwa mereka percaya banyak ASN di Provinsi Bengkulu yang mampu mengemban amanah sebagai kepala OPD.(II/440)

Kalimat pada contoh data (18) di atas konjungsi babwa menyatakan klausa pertama Ketua panitia seleksi (Pansel) lelang jabatan eselon II, Drs. Hamka Sabri, M.Si mengatakan sebagai klausa inti, klausa kedua babwa mereka percaya banyak. ASN di Provinsi Bengkulu yang mampu mengemban amanah sebagai kepala $O P D$ sebagai klausa bawahan. Konjungsi bahwa menyatakan makna isi karena klausa bawahan menyatakan isi dari klausa inti.

\section{PENUTUP}

Berdasarkan analisis data ditemukan jenis konjungsi intrakalimat dalam berita Harian Rakyat Bengkulu edisi Februari 2019 kolom utama yaitu konjungsi koordinatif, konjungsi subordinatif dan konjungsi korelatif. Konjungsi koordinatif yakni dan, serta, atau, namun, sedangkan, kemudian, lalu, yaitu, yakni, adalah. Konjungsi subordinatif yakni sejak, bingga, setelah, selama, sampai, setelah, jïka, kalau, sehingga, karena, sebab, sebagai, dengan, bahwa. Konjungsi korelatif yakni konjungsi dan...serta, dan...atau, atau...serta, dan... namun, dan...kemudian, atau...adalah, dan...sejak, hingga...dan, karena...kemudian, dan...dengan.

Fungsi konjungsi intrakalimat berita Harian Rakyat Bengkulu edisi Februari 2019 kolom utama yaitu untuk menghubungkan kalimat luas yang setara, kalimat luas yang tidak setara dan menghubungkan klausa dengan klausa. Makna konjungsi yang diperoleh dari hasil penelitian ini yakni makna penjumlahan, makna pemilihan, makna pertentangan, makna pengurutan, makna penyamaan, makna waktu, makna persyaratan, makna hasil, makna sebab, makna pembanding, makna alat, makna isi. Berdasarkan analisis yang dilakukan, jika dilihat dari penggunaannya dalam berita utama Harian Rakyat Bengkulu edisi Februari 2019 konjungsi sudah digunakan sesuai dengan fungsi dan maknanya.

Saran yang ingin penulis kemukakan yaitu penelitian ini membahas tentang konjungsi intrakalimat pada berita utama atau kolom utama Harian Rakyat Bengkulu edisi Februari 2019.Penelitian ini membahas jenis konjungsi, fungsi konjungsi, dan makna konjungsi intrakalimat. Penulis menyadari hasil penelitian ini belum sempurna dan penulis berharap akan ada penelitian selanjutnya yang akan membahas konjungsi di kolom lain seperti kolom metropolis, all sport dan kolom lainya yang ada dalam Harian Rakyat Bengkulu. Penelitian selanjutnya juga dapat menggunakan teknik analisis paradigmatik dan teknis sintagmatik, karena penelitian ini hanya menggunakan teknik analisis data subsitusi dan teknik delesi. Penelitian ini juga hanya meneliti konjungsi koordinatif, konjungsi subordinatif dan konjungsi korelatif yang berbentuk kata, penelitian selanjutnya dapat meneliti konjungsi korelatif yang berbentuk frasa.

\section{DAFTAR PUSTAKA}

Alwi, H. 2010. Tata Bahasa Baku Bahasa Indonesia. Jakarta: Balai Pustaka. 


\section{Monika Puspita Sari, Bambang Djunaidi, Supadi}

Chaer, A. 2009. Sintaksis Bahasa Indonesia(Pendekatan Proses).Jakarta: PT Renika Cipta.

Chaer, A. 2015. Marfologi Bahasa Indonesia(Pendekatan Proses). Jakarta: PT Renika Cipta.

Harian Rakyat Bengkulu, 01-28 Februari 2019.

Rahardi, K. 2002. Penyuntingan Bahasa Indonesia untuk Karang-Mengarang. Jakarta: Erlangga.

Rahardi, K. 2009. Bahasa Indonesia untuk Perguruan Tinggi. Jakarta: Erlangga.

Ramlan, M. 2008. Kalimat, Konjungsi, dan Proposisi Bahasa Indonesia dalam Penulisan Karangan Ilmiah. Yogyakarta: Universitas Sanata Dharma. 